\title{
The Experience of Border and Its Transition in Recent Russian Theater (Grishkovets, the Brothers Presnyakov, Vyrypayev)
}

In contrast to other literary genres such as novels and poetry, drama is in closer contact with the audience and thus reacts in a very sensitive way to its response: drama is not just a text addressed to readers, it is a performance that is always and primarily oriented at the theatre audience. Drama is defined as a play of interacting figures on the stage in front of viewers ${ }^{160}$. The performance and the perception by the audience happen at the same time and in the same space. They are not intermediated by reading and their perception is not interrupted ${ }^{161}$. Narrators on the scene are not common for plays and therefore cannot be seen as typical drama elements. Whereas communicative relationships on the figures' level are reciprocal, those between actors/figures and viewers are generally not, since the latter are not actively involved in the play. However, "generally" means that there are exceptions, or transgressions of traditional drama communication, very often favored for provocations (e.g. "Publikumsbeschimpfung"/ "Offending the Audience") and drama/theatrical "revolutions." One may remember the inversion of the stage and the audience in the shocking climax of Gogol's "The Government Inspector" ("Revizor") - the "mute scene" where the actors change places with the audience as the Mayor shouts: "What are you laughing about? You are laughing at yourselves!"

160 See Mahler [1994: 71] where he quotes Bentley E. The Life of Drama. London, 1965. P. 150: "The theatrical situation, reduced to a minimum, is that A impersonates B while C looks on".

161 The only genre with similar characteristics is performed lyrics, often accompanied by music (the Russian "avtorskaja pesnya," chansons, different music genres like rap etc.). It is by no means a coincidence that recent Russian playwrights in their plays use even forms as pop music, rap etc. [i.e. see Vyrypaev] which favor immediate contact with the audience. 
It is by no means a coincidence that since the late 1990s, a younger generation of Russian playwrights have chosen direct communication with the theater audience. Frustrated by the ossified theater institutions (stakeholders, journals, and traditional repertoires), the lack of interest in present-day topics, and the changes in the international drama poetics or techniques, playwrights like Aleksey Zenzinov, Maksim Kurochkin, the Presnyakov brothers, Yevgeny Grishkovets, Ivan Vyrypayev and others have searched for new forms of expression in drama. These disparate dramatic approaches challenge numerous restrictions and barriers of conservative Russian theater codes. Because of this, playwrights often get rejected by traditional institutions and receive highly critical or even negative reviews of their works. Their plays are often closely related to other arts such as music, video and film, comic, dance or light performances and similar theater projects in Central and Western Europe. The paper will highlight some aspects related to the importance of border/ margins in selected works by the Presnyakov brothers, Grishkovets, and Vyrypaev, the most popular Russian playwrights on Western stages. Since it is impossible to examine all relevant topics, I will concentrate on the selection of plays where the topic of the border is of high importance: "Terrorism" by the Presnyakov brothers, "When I Ate a Dog" by Grishkovets, and "Illusions" by Vyrypaev.

Recent Russian plays and theater production have received critical attention during the past ten years. Birgit Beumers and Mark Lipovetsky [2009; 2012] and Beumers [2012] examine the function of violence in the works of these and other Russian playwrights at the end of the twentieth and beginning of the twenty first century. While the Presnyakov brothers focus on "post-Soviet or postmodern fascism" and disclose the manifold ways it manifests itself, Grishkovets depicts individual and socially-related trauma, with a tendency towards romanticism and escapism in his recent works. In Vyrypaev, critics see the author who addresses spiritual and sacred themes, which he uses for the radical deconstruction of traditional issues, albeit in a transgressive, non-dualistic way: to be AND not to be. 
The plays display violence as a fact, which confirms the collapse of traditional communication systems [Birgit Beumers and Mark Lipovetsky 2012: 365], but its shocking effects notwithstanding, violence is represented in the form of everyday rituals. In her $\mathrm{PhD}$ thesis, Rodewald focusses on identity crisis in these plays [2014] and offers their detailed analysis. In their articles, Göbler/Rodewald [2013], Rodewald [2014] and Wolfson [2015] provide a contextualizing overview of the drama production, while other publications are dedicated to specific aspects: Kandinskaia [2014] covers the grotesque in recent drama, Gölz [2009; 2012] discusses the prose by Grishkovets, and Shevchenko [2013] focuses on the ruined celebration in "When I Ate a Dog" by Grishkovets. Numerous other short articles discuss the reception of the performances.

The importance of borderline phenomena in Russian drama is emphasized by manifold aspects of border or margins and its transition in these works and contexts. These aspects are:

1.the role of the playwrights' origin and the meaning of the province;

2. drama topics and central questions of identity in post-soviet Russia;

3. drama poetics: functions of the plays, language and drama techniques

\section{The Role of the Playwrights' Origin and the Meaning of the Province}

The aforementioned playwrights do not originally come from Moscow and St. Petersburg but from the regions and periphery instead. The Presnyakovs stem from the Ural region (Yekaterinburg), Grishkovets from Kemerovo and Vyrypaev from Irkutsk, both in Siberia. It seems that the regions develop new talents and are especially open to new literary and artificial experiments; however, the regional institutions are generally conservative. Nevertheless, new Russian drama 
is a phenomenon of "provincial occurrence" [Rudnev 2015: 66]. Many recent Russian playwrights are aware of the deep gap between capitals and provincial towns they had to leave in order to develop their potential. Grishkovets declares that "for a Russian, leaving the town means much more than for a Western European." 162 Because Vyrypaev had to leave his native city for his artistic career, he feels being "like an emigrant" in Irkutsk; even for a guest performance he is not welcome [Dokukina 2009]. Grishkovets calls his former hometown Kemerovo "a terrible place." 163 In the imagination of the latter, the direction nearly always goes one way, from the regions to Moscow which is the endpoint. While Vyrypaev and the Presnyakovs partially moved to Moscow, ${ }^{164}$ Grishkovets settled down in Kaliningrad, another extremely marginalized city without the cultural background of the capital. ${ }^{165}$ The metropolises are however not idealized either; the plots are set in provincial towns or even in the rural space, in opposition to the "alien, hostile capitals" [Gölz 2012: 96, footnote 14]. The choice of space comes from the opposition between the marginal and the central in Russia, because "( $t$ )raditional Russia is dying, the nation - especially the provinces - is becoming extinct, and traditional values are disappearing." [Rudnev 2018]. The representatives of the New Drama know the Russian province and the mental state of their inhabitants very well; they are also aware of the discrepancy between the province and the capital in the centralist-structured Russia. The awareness of the marginalized everyday life is a highly important aspect of their drama and theater work, as many of these playwrights underline. Even if they work in Moscow, they prefer small staging - underground stages especially at the begin-

\footnotetext{
${ }^{162}$ Anon. Glücklich sein ist harte Arbeit // Berliner Zeitung 31.10.2003.

${ }_{163}$ Anon. Glücklich sein ist harte Arbeit // Berliner Zeitung 31.10.2003.

164 Vyrypaev is now settled in Poland.
}

165 Anon. Glücklich sein ist harte Arbeit // Berliner Zeitung 31.10.2003. Details about the cultural scene gives this interview where Grishkovets explains the reasons to leave his native city Kemerovo; he needs a certain distance in order to write about it, not a melting pot like Moscow where dreams come to an end. 
ning of their career ${ }^{166}$ that not only demonstrates the critical attitude of their works but also the need to be in the intimate contact with the audience. These works concentrate not on established theaters, but on festivals, workshops, and theater companies searching for new ways of theatrical expression and cultural practice to "provoke, validate, puzzle, terrify, revolt, illuminate, arouse, humiliate" [Wolfson 2015: 269]. For Wolfson, New Drama ${ }^{167}$ is a diagnosis and a symptom at the same time, but due to uncertain boundaries, different plays have very different poetics [see Wolfson 2015: 270].

\section{Drama Topics and Central Questions of Identity in Post-Soviet Russia}

The New Drama works not only have a close connection with the social and existential circumstances of post-Soviet Russia, but they also respond to the decline of Russian theater since the early 1990s. They deal with the feeling of unrest and insecurity caused by social, economic, ideological, religious, and other changes as well as images of altered identity or identities in the interrelated field of individual and collective images. "The new play recognizes a person's need for self-identification $\langle\ldots>$ and is a manifestation of enormous social unrest or even social irritation" [Rudnev 2015: 65]. This marks a deep break with the traditional Russian theater that has not undergone through the "stage

166 Even the MAT (MChat) after long hesitations opened its scene for young playwrights and institutions belonging to them like the former Praktika theater after the first decade of the twenty-first century converged to mainstream theater [Göbler and Rodewald 2013: 198]. Not only this phenomenon, but also other forms of a broader perception give reason to Christine Gölz to adopt Chuprinin's term "Middle literature" ("Middl-literatura"), a literature between popular and elitist literature oriented at Yuppies [see Gölz 2012: 94-102, esp. 98].

167 The term stems from the festival name of the recent Russian drama, "Novaya drama" (since the late 1990s), the phenomenon climaxed in 2005 [Göbler and Rodewald 2013: 187; see also: http://os.colta.ru/theatre/events/details/9681]. In 2009, Beumers and Lipovetsky first dedicated a monograph to this phenomenon (translated into Russian in 2012). 
of theatrical deconstruction," 168 remaining "nostalgic" and "painfully antisocial", a theatre "which does not speak to the contemporary spectator" [ibid.]. For Rudnev, recent playwrights leave the institution of traditional theater: "The Playwrights mature outsight the theatre..." [ibid.] These plays claim their relevance for the present-day environment and appeal to the audience they want to get in close contact with.

Во всех моих пьесах есть одно общение. Это непосредственный контакт со зрительным залом. В каждой этой пьесе актеры играют для зрителя. Не важно обращается ли герой в зал или нет, это все равно диалог актера с залом. Актер при помощи роли говорит с залом. [Anon. Das Schauspielhaus Wien zeigt "Illusionen", 24.02.2013].

This aim varies, however, from a positivist position in the verbatim approach (which grounds on documentary methods of recording positions of individuals and uses them in the plays) to popular, widespread and common expectations of larger groups and even a didactical concept demonstrating and celebrating through the holy rituals and offering positive existential perspectives to the spectators, as the later Vyrypaev shows. Grishkovets wants to interact with the spectator; he advocates a concept of the individual and is not interested in performances of casts [Rodewald 2014: 19]. His characters are defined through their fear of the society, life conditions in the metropolis, and the relation between a person and mass communication and anti-globalization [see Rudnev 2018]. The main topics include life in the regions, survival, the "unholy martyr" [ibid.] condemned to the martyrdom by abysmal life conditions or the awareness of future catastrophes. The plays break social taboos the traditional theater ignores, such as nationalism and national myths, the myth of the Soviet soldier (WWII, soldier camps, and torture), faith and the Russian Orthodox Church, sexuality, violence, and social outcasts such as homeless people.

${ }^{168}$ Göbler and Rodewald [2013: 188] also underline that the established theater scene (journals, prizes) have lost the connection to the recent theater production. 
The five-act play "Terrorism" (2000) by the Presnyakov brothers published and staged in 2002, by coincidence shortly after the terroristic attack in the Dubrovka Theater in Moscow that resulted in 170 victims, discusses violence and terrorism in private and business spheres of life as well as in society. It gives a panorama of various kinds of violence and terror: an announced bomb attack on the plane, sexual violence, murder as an obvious "solution" to get rid of the unbeloved husband, revenge caused by jealousy, violence in families (by the grandmother to her grandson and vice versa), mobbing at work, and torture in the army-like institutions. Thus, it shows a vicious circle of violence, once started in childhood and continued in adult private life, which becomes a systemic phenomenon and reproduces systematically more violence. The individual acts themselves are often not terrifying; sometimes they are even trivial, i.e. a little boy ringing the bell while running away from his grandmother. However, interconnected, they lead to a catastrophe: the ringing of the bell causes a gas explosion and thus executes the plan of another character to murder his wife and her lover. To transcend this fatal circle of violence that interfuses individual and collective life, one has to strictly with draw from action.

The tumultuous farce Europe - Asia by the Presnyakov brothers, both a play and a film, in the film version also uses the classical trope of the border between the two continents in the Ural Mountains for ironic challenge of cultural stereotypes. The film allots the utmost importance as a central symbol to the border stone between Europe and Asia, which is very well known in the Russian culture. For many banished and convicted people on their way to Siberian camps, it marked the turning point of saying farewell to one's home and family for a long time or forever. A fraudulent wedding party at the "inner" border of Russia waits for the naïve foreign victims as they play the exotic Russians meeting the foreigners' expectations. Handicapped due to fatal accidents, immature Russian men depending on their mothers, drinking hard and begging for money, present a conjunction of fraternization and the "Russian soul" with 
the image of the Russian in the foreigners' perception. However, the foreigners do not believe in the "Russian culture show". A Russian emigrant in the foreigner's group who knows both the Western and Russian lifestyle picks the best for himself: using the Western benefits and swearing the West at the same time, chaotic Russia does not prevent him from acting out violence. This farce may be understood as an ironic commentary on the eternal question of cultural orientation of Russia between East and West, in the area of conflict between the "genuine" Russian, Western European, and Asian. The "Russian soul," incarnated in the "invalid's" mother, is an object of mockery: the mother, when swearing, uses typical Russian curses that contain the word "mother". The farce interrogates cultural opposites based on not knowing one another and on perpetual stereotypes and demonstrates the inadequacy of any binary-coded values. The border thus functions as a liminal space, when the perspective of every side excludes the other one. However, in a more central perspective, this border is a central part of the whole, that is Russia, and both sides are connected to each other: Western Russia, "purging" itself from all critical voices, excludes them through expulsion and Siberian camp imprisonment. Siberia, in this sense, receives the meaning of the unwilling, not-Western Russia.

Like in one of the episodes of "Terrorism", in Grishkovets" play "When I Ate a Dog", the main topics are cruelty and violence. The play highlights the inhuman treatment of individuals in a military base in the Pacific Ocean and the struggle of physical and mental surviving under the extreme sadistic conditions of a harsh hierarchy. The traumatic experience, similar to the Gulag, is in the center of the play. The nameless narrating figure is "encircling the memory, stumbling and repeating evocations of trivial everyday life's details" [Gölz 2009: 9] as he compares the present day with his schooldays when life made sense. Adolescence is over right after his birthday when all his party preparations are unsuccessful. It is part of his drama and theater concept to establish and transcend the border between the character and himself as the author; often he plays the part 
of the actor, too. ${ }^{169}$ However, he emphasizes the break and the fact that there is no borderless transition. In many of Grishkovets' plays the character has no fixed identity: here, the young man aged between 30 and 40, who used to be aware of his identity during his adolescence, had it changed during the military service. When he returned to his beloved home, he clearly understood that he was not the same person he used to be.

Я расскажу о человеке, которого теперь уже нет, его уже не существует, в смысле - он был, раньше, а теперь его не стало, но этого, кроме меня, никто не заметил. <..> понимаю, что это был не я. Нет, не я. В смысле - для всех, кто меня знает и знал, - это был я, но на самом деле тот «я», которого сейчас это рассказывает, - это другой человек, а того уже нет, и у него уже нет шансов вновь появиться... [Grishkovec 2004: 7-8]

Both on and off stage, as the narrator underlines, he as an actor and he as the character are not the same person. Grishkovets creates characters with flexible identities; people are permanently on the change. While their dreams come true, they recognize that their desires are not the same as before. Grishkovets uses oscillating, not fixed identities to show how the individual changes through a complex interdependence of collective images, gender, peer group, and other stereotypes, how she fits in different roles, persistently undergoing development.

The uncertainness of truth is the central topic of "Illusions" by Vyrypaev. This short play is about two young couples, who t alk about two old couples, all close friends, and their last time before death. Different systems of communications and problems they entail are the most important themes for Vyrypaev, who identifies he gap in communication as the main reason for things going wrong in the world [Rakovskis 2018]. Four monologues contain dialogues of the older figures and show a deeply personal recapitulation

169 There is a coincidence that Grishkovets himself served the navy at such a base for three years; this is no secret since he underlines this fact in interviews. 
of the couple's love relationships. Danny before his death thanks his wife Sandra for her lifelong love and claims he never betrayed her. When Sandra dies a year after, she confesses her love to her husband's best friend, Albert, the only love of her life. The story of Albert and Margret also reveals a secret: after Sandra's death, Albert tells Margret that he only now understands what true love is, that they never shared it, and that he loved Sandra all the time. Margret responds to him that she had a secret relationship with Danny for over more than 50 years. The circle of the totally different perception of reality seems to be perfect. However, Margret, who is said to be a "humorous" woman, after her husband's confession commits suicide and leaves a letter where she confesses that her love for him was the most important truth in her life. Ten years later, when Albert understands the meaning of this letter, he suddenly dies.

There is nothing certain about existential emotions such as mutual love, as the title of the play "Illusions" points out. These emotions are liable to changes through time and as other persons become engaged; they are not eternal phenomena. Things are not what they seem to be at first sight: Margit's humor is just a way of dealing with serious issues; old age is no guarantee of wisdom as the childish, immature Albert's character demonstrates; confessions can be expressions of a moment or a whim; long-lasting relations do not guarantee the lasting of feelings etc. There is no definite truth in life but an eternal human desire for unchangeability [see Noack 2011: 23]. Language thus has a manipulative and ideological function because it creates a virtual reality, which cannot be verified. Emotions and empathy are of high importance to all aforementioned playwrights: they are the basic need of every human and are never linked to "intellectual concepts" [see Vyrypaev in Wilmes 2018: 239]. The plays appeal to action, show the performance from stage to life; they seek to engage the spectator not in a rational, but in an emotional way. The spectators should feel that the performance is engaging them in something transcendent to their life and that drama is not art per se but a bridge between art and real life. 


\section{Drama Poetics: Functions of the Plays, Language, and Drama Technique}

The New Drama's poetics breaks with the predecessors in the Russian dramaturgy, not only concerning topics, but also in the choice of means. One of the most important devices is the demand of straight communication with the audience, which should make them understand that the topics have direct connection to their life. The plays widely use spoken language - either in a documentary way through the verbatim method ${ }^{170}$ or in another authentical way, without focusing on the more traditional literary language. Therefore, Russian swearing ("mat") is also part of these plays, sometimes even in the announcements ("Attention! In what follows, normative words will not be used!"), ${ }^{171}$ and the "big split in Russian Language" plays here a significant role [Serebrennikov in Kandinskaia 2012: 104]. However, the language contains slang elements, but in general, it is a "neutral" language - Gölz calls it a "zero language" ("NullSprache") - neither vulgar ("prostorechie") nor "literary language" [Gölz 2012: 99]. Typical characteristics of blogging like transition of the borders of the literary language towards the freedom of expression as analyzed by Schmidt [2012: 64-65] are also common for these plays; therefore, it is no wonder that Grishkovets, who is blogging up to the present day ${ }^{172}$, uses such language. The key element of authenticity is the expression of emotions and subjectivity; these plays regularly provoke emotional reactions among the spectators, frequently through the portrayal of violence. ${ }^{173}$

${ }^{170}$ Grishkovets rejects this documentary method claiming that recorded spoken language does not express the important sense, but the kind of speaking, and that dramatic language has to express the essential meaning.

${ }^{171}$ This was harshly criticized by established critics and political institutions which was a reason for not permitting such plays since 2014 .

172 URL: https://odnovremenno.com/ (accessed: 13.02.2020).

${ }^{173}$ Nevertheless, there are even contrary tendencies in recent Russian plays. Thomas [2018] observes a new trend, "the return of the 'play' in verse and the formalistic devices of rhyme, rhythm, and structure associated with it." 
Not only words provide a basis for the plays; music and dance are also of high importance for the performances of these plays and films, ${ }^{174}$ alongside other kinds of visual arts (film, video projections and light effects) as well. The aim is to evoke emotional reactions and to establish associations beyond rational logic in drama, also through unstable characters with fluid or open identities. In order to involve the audience directly, sometimes even the seating arrangements are changed in order to confront two groups of the audience with one another (by expanding the stage onto the audience via such a device as a catwalk in 2013 in Chemnitz).

The actors' performance underlines the general openness of identity. The play does not support the spectator's identification with the figure, actors play multiple roles, and especially Vyrypaev stresses the lack of emotions in the actor's mimics serving to force the spectator to experience her own feelings [see Rodewald 2014: 307]. Narrative parts dominate the plays and cause a feeling of alienation, which is needed to prevent the viewers from identifying with the characters, for the sake of a general distance and cognition. Characters talk about their experiences, memories, and self-reflections ("How I Ate a Dog"); they narrate the stories of other characters, reciting their speeches, but not playing them. Single "worldviews" get lost in multiple perspectives, like in "Illusions" [see Gambihler]. If they perform characters, they show through a fatal relatedness "the dissolution of boundaries" to each other [Wolfson 2015: 271]. "Terrorism" shows that the borders between things and persons are not fixed, as it seems to be at first.

${ }^{174}$ Besides the plays, nearly all of the mentioned playwrights shot films with the same "story". Vyrypaev seems to be most influenced by music and dance, see "Kislorod" or even "Delhi Dance" with its title. 


\section{Conclusion}

The mentioned playwrights (along with some others, such as Sigarev) are attendant in Russian metropolis theaters and highly popular especially in Central, Eastern, and Southeastern European theater; some of the playwrights even got booked by theaters for custom plays (Berlin, Chemnitz a.o.). Sometimes, Western stages introduce "typical Russian" images as representations of Russian culture for popular effects on a foreign audience: a matrjosh$\mathrm{ka}$ and a big bottle of vodka in the stage setting of "Illusions" in Chemnitz ${ }^{175}$ or drunkenness. ${ }^{176}$ Such a staging undermines generalizations in meaning and restricts them in a problematical way. However, the mentioned plays are open not only to the problems of Russian society but to general, global problems and thus exceed specific circumstances related to Russia. They often choose international, non-specific locations, "cosmopolitan personae and settings," as Wilmes [2018: 237] claims about Vyrypaev's plays. These topics and new theater poetics have developed in close exchange with European scenes and made them relevant for theaters outside of the Russian cultural sphere, too. The plays are often mocking national and collective stereotypes, representing them as barriers for communication that cause hatred and violence. By using topics of the marginality in everyday life, new aesthetics, and new ways of communication, recent Russian drama, as it follows anti-rationalistic and anti-illusionistic tendencies, crosses the borders of traditional theater work and finds new ways to address young spectators, especially showing and evoking emotions [see Ageeva 2013: 173].

175 These symbolic signs could lead to interpretations, connecting the performances with typical Russian problems, which is not intended.

176 In the central narrative of drunkenness in "The Drunks" two semantic spheres are mixed: The physical misuse of alcoholics - one of the most popular Russian images in the West -, and the condition of transgression in the mind. The program at Schauspielhaus Graz is dedicated to the meaning of the central metaphor of inebriation, which enables to show emotions and to pass borders of the predestinated. 
Discussing aspects of cultural identity and transgression of national and collective items, the New Drama playwrights open access to international cultural communication.

\section{Works cited}

Anon. Glücklich sein ist harte Arbeit // Berliner Zeitung. 31.10.2003. URL: http://www.berliner-zeitung.de/gluecklich-seinist-harte-arbeit-hebbel-am-ufer-jewgnij-grischkowew--der-erneuerer-der-moskauer-theaterszene--kommt-mit--dreadnoughts--und-planeta--nach-berlin-15786830 (accessed: 09.06.2016).

Anon. Die Einsamkeit bleibt// Der Standard. 28.05.2002. URL: http://derstandard.at/964614/Die-Einsamkeit-bleibt (accessed: 09.06.2016).

Anon. "Kislorodnoe" golodanie // Konkurent. 16.09.2006.

Affenzeller M. Die Flotten der Einsamkeit // Der Standard. 03.09.2003. URL: http://derstandard.at/1312286/Die-Flotten-der-Einsamkeit (accessed: 09.06.2016).

Behrendt E. Die zweite Geburt // Theater heute. 2015. 5. S. 20-22.

Betrunkene. Iwan Wyrypajew. Schauspielhaus Graz, 2016.

Beumers B., Lipovetsky M.N. Performansy nasiliya. Literaturnye i teatralnye eksperimenty "novoi dramy". Moskva, 2012.

Briegler T. Haltestelle Dreiunglücksweg // Theater heute. 2006. 2. S. 8-11.

Gambihler $R$. Theoretische Sommernachtsträume. "Illusionen" - der russische Dramatiker Iwan Wyrypajew wirft einen ironischen Blick auf die wahres Liebe // Nachtkritik. 29.09.2011. URL: $\quad$ https://www.nachtkritik.de/index.php?option=com content $\&$ view $=$ article \&id=6116:illusionen-iwan-wyrypajew-urauffuehrung-dieter-boyer-chemnitz\&catid=296\&Itemid $=100190 \quad$ (accessed: 24.01.2020).

Göbler F., Rodewald S. "Novaja Drama". Neubeginn russischer Dramatik und Trendwende in der Bühnenkunst zu Beginn des 
21. Jahrhunderts // Theaterlandschaften der Gegenwart: Rahmenbedingungen und Zeitbezüge im zeitgenössischen Drama. Eds. A. Gall \& G. Nickel. Tübingen, 2013. S. 187-204.

Gölz C. Wie Evgenij : Griškovec «Hemd» gemacht ist // Arbeitspapiere des Osteuropa-Instituts. 2009. 1. S. 4-24.

Gölz C. Ernst als Spiel oder Helden der Uller Jahre: Evgenij Griskovec' Rubaška (Das Hemd) // Wiener Slawistischer Almanach, 2012. 79. S. 85-110.

Grund S. Der Mensch hat einen ganz schönen Urknall // Die Welt. 09.03.2015. URL: http://www.welt.de/kultur/buehne-konzert/ article138190013/Der-Mensch-hat-einen-ganz-schoenen-Urknall. html (accessed: 08.06.2016).

Haider-Pregler $H$. Einsam im Großstadtdschungel // Wiener Zeitung. 29.05.2002. URL: http://www.wienerzeitung.at/nachrichten/kultur/buehne/185136 Einsam-im-Grossstadtdschungel.html (accessed: 09.06.2016).

Haider-Pregler H. "Unheroische" Reflexionen. Schauspielhaus: Jewgenij Grischkowez in «Dreadnoughts»// Wiener Zeitung. 26.05.2003 URL: http://www.wienerzeitung.at/nachrichten/ kultur/buehne/165278 Unheroische-Reflexionen.html (accessed: 09.06.2016).

Kandinskaia N. Postmoderne Groteske - groteske Postmoderne? Eine Analyse von vier Inszenierungen des Gegenwartstheaters. Münster, 2012.

Lange B., Weller N., Witte G. Chancen, Taktiken, Umwege, Lebensentwürfe im russischen Film und Roman der Jahrtausendwende // Wiener Slawistischer Almanach. 2012. 79. S. 5-25.

Mahler A. Aspekte des Dramas // Literaturwissenschaft. Ein Grundkurs. Eds. H. Brackert \& J. Stückrath. Reinbek, 1994. S. 71-85. Meierhenrich D. "Unerträglich lange Umarmung" von Iwan Wyrypajew. Ein Netz aus Frust, Naivität und Esoterik // Berliner Zeitung. 06.03.2015. URL: http://www.berliner-zeitung.de/kultur/unertraeglich-lange-umarmung-von-iwan-wyrypajew-ein-netz-ausfrust-naivitaet-und-esoterik-871556 (accessed: 13.02.2020). 
Meierhenrich D. Schönes Untergehen: Jewgenij Grischkowez «Dreadnoughts» im HAU 1 Schlachten mit Papierschiffen // Berliner Zeitung. 08.11.2003.

Noack B. Mehr Luft. Iwan Wyrypajew "Sauerstoff" // Theater heute. 2005. 5. S. 41-42.

Noack B. Das Leben machte schlechte Witze // Theater heute. 2011. 12. S. 22-23.

Rakovskis A. Ivan Vyrypaev On Cinema, Theatre, And His Dreams // The Theatre times. 20.12.2018. URL: https://thetheatretimes.com/ivan-vyrypaev-on-cinema-theatre-and-his-dreams/ (accessed: 14.02.2020).

Rodewald S. Auf der Suche nach der verlorenen Identität: Das Phänomen «Novaja Drama». Die postsowjetische Identitätskrise im Spiegel der russischen Gegenwartsdramatik (1997-2014). Dissertation. Mainz, 2014.

Rudnev P. The New Play Dramaturgy in Russia // The Routledge Companion to Dramaturgy. Ed. M. Romanska. London, New York, 2015. P. 62-67.

Rudnev $P$. The new play dramaturgy in Russia // The Theatre times. 25.01.2018. URL: https://thetheatretimes.com/the-new-playdramaturgy-in-russia/ (accessed: 13.02.2020).

Sander N. Die literarische Performance von Evgenij Griskovec // Osteuropäische Lektüren II. Texte zum 8. Treffen des Jungen Forums Slavistische Literaturwissenschaft. Eds. M. Jakiša, Th. Skowronek. Frankfurt/Main, 2009. S. 157-175.

Schmidt H. Ein Jahr im Leben des Evgenij Griškovec. Inszenierte Authentizität und die Rückkehr der Aura. Wiener Slawis-tischer Almanach. Sonderband. 2012. 79. S. 57-84.

Thomas A. Moscow's 2018 Liubimovka Festival. New Trends, OldProblems//TheTheatre Times. 12.10.2018.URL: thetheatretimes. com/moscows-2018-liubimovka-festival-new-trends-old-problems (accessed: 13.02.2020).

Vyrypaev I., Schmidtke S. Unerträglich lange Umarmung // Theater heute. 2015. 5. S. 3-15. 
Vyrypaev I., Schmidtke S. Illusionen // Theater heute. 2011. 12. S. $2-10$.

Weigel M. Unerträglich lange Umarmung - Iwan Wyrypajews neues Stück am Deutschen Theater Berlin uraufgeführt // Nachtkritik. 06.03.2015. URL: http://nachtkritik.de/index.php?option=com content\&view=article\&id=10639:2015-03-06-06-40-24\&catid=38:dienachtkritik\&ltemid=40 (accessed: 24.01.2020).

Wilmes J. "Stability amidst chaos": Subjective Re-orientation in Ivan Vyrypaev's Delhi Dance (2013) and Unbearably Long Embrances (2015) // Studies in Russian and Soviet Cinema. 2018. 3. P. 232-250.

Wolfson B. New Drama // Russian Literature since 1991. Eds. E. Dobrenko \& M. Lipovetsky. Cambridge, 2015 P. 268-283.

Агеева Н.А. Поэтика современной отечественной монодрамы // Вестник Новосибирского государственного педагогического университетаю. 2013. № 6. С. 168-176.

Вырыпаев И.А. Пьесы. М., 2016.

Гришковеи Е. Лето-лето и другие времена года. М., 2017.

Гришковеи Е. Как я съел собаку. М., 2004.

Докукина $K$. Чувствую себя в изгнании // Кункурент. 25.07.2009. URL:_http://www.vsp.ru/2009/07/25/chuvstvuyusebya-v-izgnanii/(дата обращения: 13.02.2020).

Шевченко Э. Церковная проповедь и придворный праздник в 1740-х годах // Festkultur in der russischen Literatur (18. bis 21. Jahrhundert). Ed. A. Graf. München. S. 275-280. 


\section{Аннотация}

\section{Ренате Хансен-Кокоруш (Грац)}

Опыт границы и ее преодоления в современном русском театре (Гришковец, братья Пресняковы, Вырыпаев)

На основе отдельных пьес современных представителей «новой драмы», Ивана Вырыпаева, Евгения Гришковца и братьев Пресняковых, анализируется феномен границы и ее изображение в современной русской драме. Обсуждение ведется на разных уровнях: значение провинции и центра или главного города, драматические сюжеты, социальные проблемы, изображение персонажей, их коммуникации и вопросы идентичности. Особенности языка, драматические техники и функции рассматриваются в аспекте категории «граница». Несмотря на то, что каждый из этих авторов представляет особою драматическую поэтику и использует разные драматические регистры и языки, их объединяет оппозиционность по отношению к традициональному театру, с которым они порывают, противясь его упрощенности. Персонажи показаны в развитии, в преодолении ими различного рода границ, стереотипы порой высмеиваются, а одну из важнейших задач составляет эмоциональное вовлечение зрителей.

Ключевые слова: Новая драма, граница, провинция, драматический язык, идентичность, эмоции. 


\section{Summary}

Bearing on several plays by contemporary representatives of the "New Drama," Ivan Vyrypaev, Yevgeny Grishkovets, and the Presnyakov brothers, the essay analyzes the phenomenon of the border and its image in modern Russian drama. The texts are discussed at different levels: the meaning of the province and the center or the main city, dramatic stories, social issues, portrayal of characters, their communication and identity issues. Features of language, dramatic techniques and functions are examined under the category of the "border". Despite the fact that each of these authors represents a special drama poetics and uses different drama registers and languages, they are united in their opposing to traditional theater: they negate the latter by confronting its simplification. The characters are shown in evolution, in overcoming various boundaries, stereotypes are sometimes ridiculed, and one of the most important tasks is the emotional involvement of the audience.

Keywords: New Drama, border, province, drama language, identity, emotions. 